Article

\title{
A Participatory Analysis of the Control and Certification System in the Italian Organic Rice Value Chain
}

\author{
Giovanni Dara Guccione ${ }^{1}\left(\mathbb{D}\right.$, Elena Pagliarino ${ }^{2}{ }^{-}$, Ilaria Borri ${ }^{1}$, Alessandra Vaccaro ${ }^{1}$ and Patrizia Borsotto ${ }^{1, *}$ \\ 1 CREA Research Centre for Agricultural Policies and Bioeconomy, 00198 Rome, Italy; \\ giovanni.daraguccione@crea.gov.it (G.D.G.); ilaria.borri@crea.gov.it (I.B.); \\ alessandra.vaccaro@crea.gov.it (A.V.) \\ 2 CNR-IRCRES National Research Council, Research Institute on Sustainable Economic Growth, \\ 10024 Moncalieri, Italy; elena.pagliarino@ircres.cnr.it \\ * Correspondence: patrizia.borsotto@crea.gov.it; Tel.: +39-347-3601750
}

check for updates

Citation: Dara Guccione, G.; Pagliarino, E.; Borri, I.; Vaccaro, A.; Borsotto, P. A Participatory Analysis of the Control and Certification System in the Italian Organic Rice Value Chain. Sustainability 2021, 13, 2001. https://doi.org/10.3390/su 13042001

Academic Editors: Valeria Borsellino and Emanuele Schimmenti

Received: 6 December 2020

Accepted: 9 February 2021

Published: 12 February 2021

Publisher's Note: MDPI stays neutral with regard to jurisdictional claims in published maps and institutional affiliations.

Copyright: (c) 2021 by the authors. Licensee MDPI, Basel, Switzerland This article is an open access article distributed under the terms and conditions of the Creative Commons Attribution (CC BY) license (https:// creativecommons.org/licenses/by/ $4.0 /)$.

\begin{abstract}
Italy is the leading European rice producer. The transition to organic farming of rice farms could represent a solution for environmental protection, as well as for their economic sustainability, consumer safety, and as a measure of climate mitigation. However, there are currently several weaknesses in the control and certification system. The objective of the current study was to propose advice for improving the control and certification scheme in the organic rice sector. The goal was achieved by adopting a qualitative methodology based on participant observation at stakeholder meetings and community-led workshops, and information collected in focus groups and deep interviews with relevant local actors. The findings show that there are some solutions to mitigate the weakness of the Italian certification scheme. The study also contributes to improving the Italian organic rice sector by highlighting that a revision of procedures and sanctions alone is not enough, and that an ethical and cultural change is also needed along the whole value chain.
\end{abstract}

Keywords: qualitative research; regulations; ethical issues; sustainable production

\section{Introduction}

Certified organic products are produced, stored, processed, handled, and marketed in accordance with precise technical specifications (standards), which in the European Union (EU) are established by EU Reg. 889/2008 and certified by a certifying body (CB). The latter is responsible for verifying that the operator acts in compliance with organic rules, and if verified, the product can be labelled as organic. This label differs depending on the standard (for example, for products from the EU it is set in Annex XI of Reg. 889/2008) and it can be taken as an assurance that the elements constituting an "organic" product have been met [1].

In the EU, every country appoints a "competent authority" who is ultimately responsible for making sure that EU organics rules are followed. This competent authority can delegate the certification of the products to (i) one or more private certifying bodies, (ii) one or more public control authorities, or (iii) a mixed system with both private certifying bodies and public control authorities [2]. In Italy, for example, the competent authority is the Ministry of Agricultural, Food and Forestry Policies (MiPAAF) and it delegates 20 private certifying bodies, 18 in the whole Italian territory and two specific to the autonomous province of Bolzano [3].

Beyond the specific mechanisms of the control system, the organic standards, legislation, and certification systems were developed to ensure the quality of organic produce. One of the main challenges facing organic agriculture is establishing and maintaining credibility of the system and professionalism of the stakeholders (SHs), particularly farmers and certifying bodies. Correcting the inadequacies in the regulatory framework and 
ensuring stringency of the control system for global consumers while allowing for locally appropriate adaptations are the major issues at stake in this respect [4].

The Italian organic rice sector offers an excellent case to reflect on these aspects and on the strategies to maintain and strengthen the effectiveness of organic certification.

\subsection{The Italian Organic Rice Sector within the World Context}

Rice was the first cereal produced worldwide for human consumption, and is second after corn for quantity of production. In the world there are more than 140,000 varieties of rice and many typologies of cultivation [5]. Rice is produced in many areas with different weather conditions, from the rainiest areas in the world to the driest deserts [6]. According to the Research Institute of Organic Agriculture (FiBL) [7], in 2018 the world land area dedicated to organic rice production was about 566,000 hectares and represented about $0.35 \%$ of the total world land area for rice production ( 160 million hectares). Most of the organic rice agricultural area is in Asia ( $87 \%$ ) and 332,000 hectares $(60 \%$ of the total organic rice area) are in China (Figure 1). Thailand with 67,000 hectares (in the past 10 years the organic rice area has risen from 17,000 to the current figure), Indonesia with 54,000 hectares, and Pakistan with 31,000 hectares are the main producers of organic rice; Italy, with less than 20,000 hectares, is the top non-Asian country.

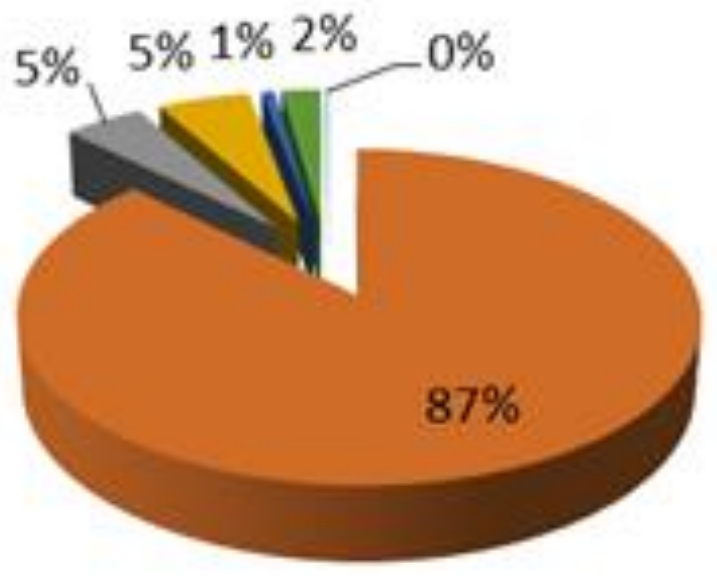

Africa

Asia

EU

Europe

Latin America

Northern America

Figure 1. World organic rice area in 2018: geographical distribution, our elaboration on FiBL data [7].

Italy is also the leading European producer, followed by France, Romania, Greece, and Spain (Figure 2). In the last five years, as shown in Figure 2, the rice land area has increased rapidly (EU: $+52 \%$ ) with countries that have showed a considerable growth (France: $+95 \%$ and Italy: $+64 \%$ ), following the positive trend that has characterized the European organic sector [8]. This increase is matching the increased European consumer demand for high quality food production that respects the environment, complies with animal welfare, and supports the development of rural areas [9]. Moreover, the consumption of rice has increased as consumers' diets have diversified from traditional starchy food components such as bread, pasta, and potatoes [10].

Organic rice land area has experienced a twofold increase in Italy during the last 10 years, growing faster than the rest of all organic crops (Figure 3). 


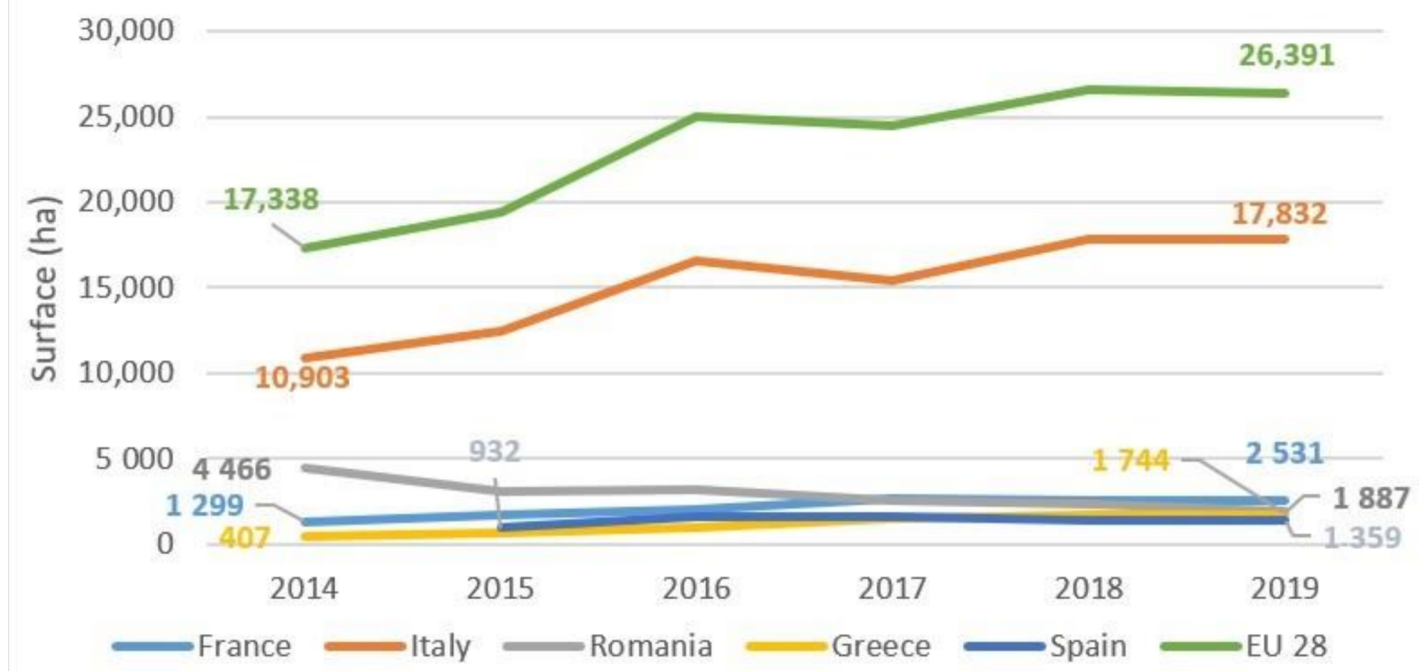

Figure 2. European organic rice land area: main countries-years 2014-2019, hectares, our elaboration of EUROSTAT data [11].

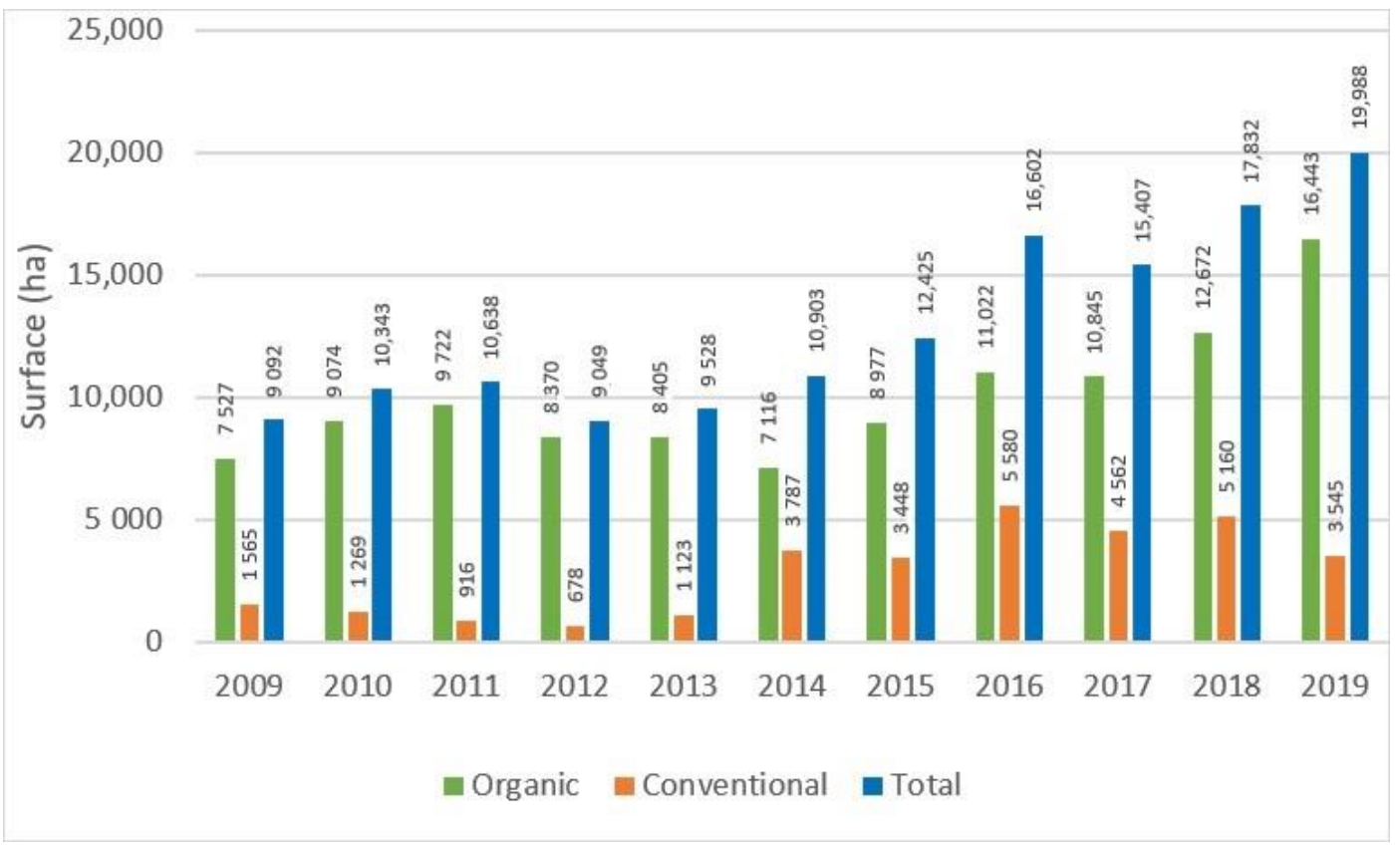

Figure 3. Evolution of the organic rice-cultivated area in Italy, years 2009-2019, hectares, our elaboration of Italian National Information System on Organic Farming data [12].

Italian rice production is localized in Northern Italy and precisely in two RegionsLombardy and Piedmont-that concentrate $98 \%$ of the land area invested in organic rice. Organic rice is also cultivated in Lazio (1500 hectares), Veneto (375 hectares), and Sardinia (55 hectares) [12].

In 2019, the organic method was adopted in Italy by 80,643 operators on about two million hectares. Italian organic rice production has always been practiced by a niche of pioneer producers because of the difficulties in cultivating rice without the use of chemicals, especially those for the containment of weeds, and the lack of specific dedicated research and dissemination [13]. The water management system within districts that include both conventional and organic farms does not allow the absence of chemical pesticide residues in the waters used for the organic crop to be assured. 
However, in the last few years, organic rice has registered an increasing interest by farmers due to different factors. The prices of conventional rice have been penalized by the competition of rice imported from developing countries, whereas the price of organic rice has continuously increased due to a general lack of supply. This economic situation, combined with the absence of chemical residues in the final processed product, encouraged some farmers to produce rice conventionally, but managing to obtain an organic certification. Clearly this has been possible because the control and certification system (CCS) had flaws that prevent it from identifying fraudulent situations. At the end of 2014, the phenomenon of so-called "fake organic" exploded, causing a still-ongoing crisis in the entire Italian sector, with tensions between rice farmers, accusations and suspects, speculation on lands, journalistic inquiries, and investigations by the competent authorities. With the emergence of the inefficiency of the CCS, it has been clear that the problem of the integrity of the supply chain was not only a concern of the certifying bodies (CBs) or the supervisory authorities, but also an ethical, cultural, and educational problem that affected the whole supply chain, and that a radical change was required to guarantee the reliability and transparency of the sector [14].

The Italian rice system is distinguished by the presence of an interprofessional public economic body, the Ente Nazionale Risi, under the supervision of the MiPAAF. This agency takes care of the image of "made in Italy" rice in information campaigns and liaison actions between operators in the value chain to facilitate the placement of the product. In addition, pursuant to Legislative Decree $\mathrm{n}^{\circ} 131$ of 4 August 2017, it also controls the product marketed in Italy and controls the traceability of "classic" rice.

\subsection{Research Questions and Theoretical Framework}

In this critical context, the goal of the study was to answer the following research questions: The duty of the regulatory system is to guarantee the quality of the products, but if there are flaws and the system is no longer efficient, is the responsibility to be attributed only to the CCS or should it be shared between all the players in the supply chain? Is it possible to imagine that, alongside a revision of the legislation, a self-regulation process takes place between farmers and other stakeholders in the value chain?

These questions need to be considered in light of the theoretical framework of the organic farming CCS and the movement that is taking place and that sees the establishment of a quality certification system parallel to the traditional one.

Organic agriculture and its certification system poses a great challenge for the producers as well as the controllers to ensure the authenticity and high quality of the products. Furthermore, they challenge academics to better understand the concept of authenticity, how it evolves over time, and the systems deployed to ensure it [15]. According to Parrot et al. [16], the growth of organic agriculture in developing countries follows two main organizational trajectories: a highly visible and rapidly growing, formal certified sector and a less easily quantified, informal or agro-ecological sector (see also Loconto [17]). The former is clearly oriented towards global commodity chains and is intended to bring benefits to producers by offering premia for ecological production and to consumers by guarantying the quality of the products. The latter approach implies a reconceptualization of organic farming as farming practices that rely upon ecological principles and knowledge associated with an ethical and cultural transition and with local development priorities. Although some who practice and promote non-certified organic farming explicitly align themselves with the organic movement, many others do not—and some even appear to distance themselves from such an association.

Darnhofer et al. [18] used the term "conventionalization," criticizing how big actors of the agroindustry invested in the organic sector, becoming dominant and often to the detriment of organic principles.

Nelson et al. [19] added that mainstream certification systems have been criticized for promoting an input substitution vision of organic agriculture and for being inaccessible to 
small-scale producers, primarily in the Global South, where alternative organic certification systems have begun to be implemented.

The affirmation of an alternative certification movement that is parallel to the conventional one also occurs in Europe, where several examples [20-22] documented the need for a system of compliance with organic principles based on relationships of trust, shared values, and commitment between different actors in the supply chain, in addition to or in place of the conventional certification system.

The question of ethics [23,24]; the local, community-based dimension [19]; a stronger connection between farmers and consumers, and more generally between the actors of the supply chain and the local communities and territories [4,5]; and relational processes of association and dissociation [25] play an important role in the evolution of organic farming and the related CCS. The possibility of dialogue between government and private intervention is another useful element of regulatory capabilities of the organic sector [26]. An underlying theme in such challenges is one of balancing competing needs. The organic movement now has many SHs, and these voices all deserve to be heard in such an overtly democratic movement [4].

Pyburn et al. [27] advocated for a mixed mechanism to stimulate and provide incentives for social responsibility throughout the supply chain. To achieve more than superficial change in social responsibility, a learning approach can be developed in which various $\mathrm{SHs}$, including farmers and certification agency representatives, meet for discussions, out of which comes a new understanding for farmers (e.g., more technical knowledge about organic farming, expanded personal networks) and agency staff (e.g., more knowledge about local constraints for organic production), and ultimately refined standards and certification methods are produced. Ideally, the standards are temporary and always subject to revision, and are the outcome of a cooperative learning process rather than an instrumental process dominated by a few powerful interests.

Strategies to maintain and strengthen the effectiveness of organic certification have been identified and include (i) internal control systems as a tool for smallholder group certification, (ii) participatory guarantee systems in formalized regulatory systems, (iii) complementary regulatory structures to provide assurance across sectors and regions, (iv) transparent auditing and verification systems, and (v) approval of allowable inputs based on peer-reviewed science [4].

Commonly referred to as Participatory Guarantee Systems (PGSs), this form of certification is based on mainstream organic standards. However, it takes place at the community level, involves a wide variety of actors, employs simple verification procedures, minimizes bureaucracy and costs, and incorporates an element of environmental and social education for both producers and consumers [19]. The adoption of alternative quality assurance systems is based on the collective responsibility of the SHs (producers, consumers, distributors, technicians, etc.), on a common vision of seriousness, professional integrity, and mutual trust [28]. The development of PGSs reflects the growing "beyond organic" movement, which wants to go over organic certification and focuses on the reconstruction of a local food system immersed in the social and ecological context from which it comes [19].

Therefore, this article reflects on the role of the CCS, but also on the role of the other SHs in improving the transparency and the seriousness of the supply chain. Therefore, the present research on the critical issues and possible solutions of the CCS of Italian organic rice cultivation is not only limited to the analysis of regulatory measures and to questioning the responsible parties, but is also extended to collecting the point of view of farmers, their representatives in farmers' unions, industry experts, public officials, and other relevant SHs. The analysis leads to the conclusion that the critical heterogeneity of the certification system can find an answer in mandatory adjustments of the regulatory system, but also in spontaneous and voluntary actions by producers, taken in agreement with each other and with other actors in the value chain and aimed at restoring a condition of widespread trust.

Several studies showed that heterogeneity of CCS might influence not only CBs ${ }^{\prime}$ performance, but also the credibility and efficiency of the whole system [29-35]. 
As suggested by other authors [36], an improvement of the organic control system could be realized through improved supervision and prevention of both intentional and unintentional types of fraud.

The analysis of how the CCS operates can provide useful results for improvement in its design, enhancing its complementarity with public rules [37]. In this research, the point of view of final consumers or their associations was not investigated because the Italian control and certification system is currently still very far from a participatory system (e.g., PGSs) that does not foresee their involvement. In addition, it was considered that their involvement in this exploratory phase might alarm consumers, who, not knowing the mechanisms of the CCS, could misinterpret the current inadequacies and the risk to consumer health.

Answering the research questions, the study aimed to propose advice for improving the control and certification scheme in the organic rice value chain.

The following sections of the paper deal with the strategy and methodology adopted in the study, and the outcomes and discussion of the analysis providing the present findings. In the final section the authors discuss the results and conclude the work by providing implications and suggestions for future research.

\section{Materials and Methods}

In this paper we analyzed the legislative framework on organic farming and regarding the CCS. We conducted a desk analysis on all EU regulations and Italian national laws regarding the previous subjects. On the base of the legislation framework, the field analysis investigated the opinions of the various actors of CCS as well as those of the rice sector to obtain a reliable and detailed framework of critical issues and possible solutions for improving it.

\subsection{The New EU Regulation on Organic Farming}

The desk analysis examined the latest legal basis: the new European regulation on organic production and labelling of organic products (Regulation (EU) 2018/848) and the new Italian control decree (Decree law $\mathrm{n}^{\circ} 20$ of 2018).

The Italian legislative decree repeals the previous one from 1995, updating the provisions on controls in organic farming and introducing for the first time an administrative sanction system (previously, minor non compliances were not prosecuted). This decree reorganizes and simplifies in a single document the principles and rules that harmonize the control and the certification system of the production, processing, marketing, and importing of products obtained according to the organic farming method.

The new legislation maintains the following architecture of the control and supervision system (Figure 4):

- $\quad$ MiPAAF is the competent authority. It periodically verifies the maintenance of the $\mathrm{CBs}^{\prime}$ requirements. This activity is carried out jointly with the Department of Central Inspectorate for Fraud Repression and Quality Protection of the Agri-Food Products and Foodstuffs (ICQRF), and by the regions and autonomous provinces within the territory of their competence and by the Carabinieri Forestry, Environmental and Food Command Unit (CUTFAA);

- Control is delegated to the CBs, such as independent private bodies responsible for verifying the correct application of the regulations of the organic method. In Italy there are 20 authorized $\mathrm{CBs}$; and

- ACCREDIA is the national body authorized by the Italian Ministry of Economic Development to carry out CB accreditation according to the ISO standard, a requirement for CBs to be recognized by the MIPAAF and be able to enter the into the control system. 


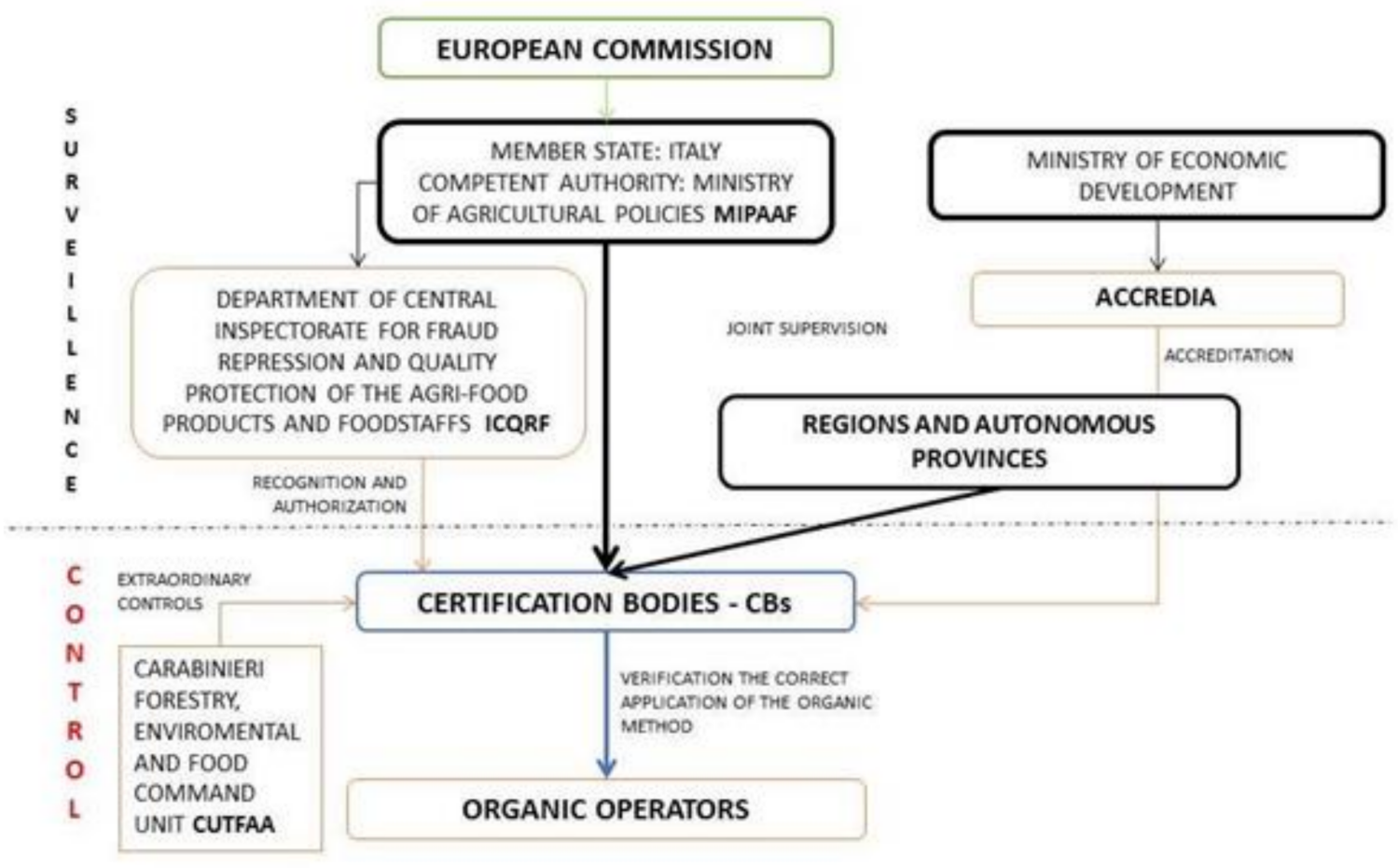

Figure 4. The actors of the Italian organic certification, control, and supervision system.

The control decree has rationalized and made the supervisory and control activity more effective by improving coordination and collaboration between the subjects of the system. However, a well-designed system can be fallacious if the necessary and timely information flow is not ensured. The decree therefore provides that the subjects of the supervisory and control system sign agreements and memoranda of understanding about the sharing of information of the administrative procedures required by European legislation, through the Organic Farming Information System (OFIS). This system centralizes information that was previously available at the level of 19 regions and two autonomous provinces. The effectiveness of the control system is attributable to the connection of the information flow between the OFIS and the supervisory database, which represents the common and shared information base through which the data of the supervision activity carried out by the CBs are collected and made available to the competent authorities.

The decree provides penalties for false designation, presentation, and labelling of organic products both for commercial purposes and for information for consumers, at the expenses of all operators in the supply chain.

Finally, the control decree adopts a measure to guarantee the constant improvement of the efficiency and effectiveness of control and supervision activity by assigning 50 percent of the proceeds from the sanctions to public supervision activity.

The new Regulation (EU) 2018/848 on the production and labelling of organic products, which enters into force on 1 January 2022, envisages new obligations for operators, i.e., preventive measures aimed at guaranteeing the conservation of biodiversity and the quality of the soil and precautionary measures aimed at avoiding contamination by products or substances not authorized for use in organic production, and avoiding mixing of organic products with non-organic products.

The regulation introduces the certification of groups of operators that simplifies adherence to the organic production method for small producers by reducing certification costs. Finally, the regulation includes a ban on the import into the EU of organic products obtained in developing countries that do not have the same set of rules as those producing in the EU. 


\subsection{Field Analysis}

The Italian CCS of organic rice cultivation was investigated as a case study, with a qualitative approach combining different techniques and tools.

The views of different $\mathrm{SHs}$, which were directly involved in the production, processing, and certification of the organic rice supply chain, were collected as shown in the following Figure 5 .

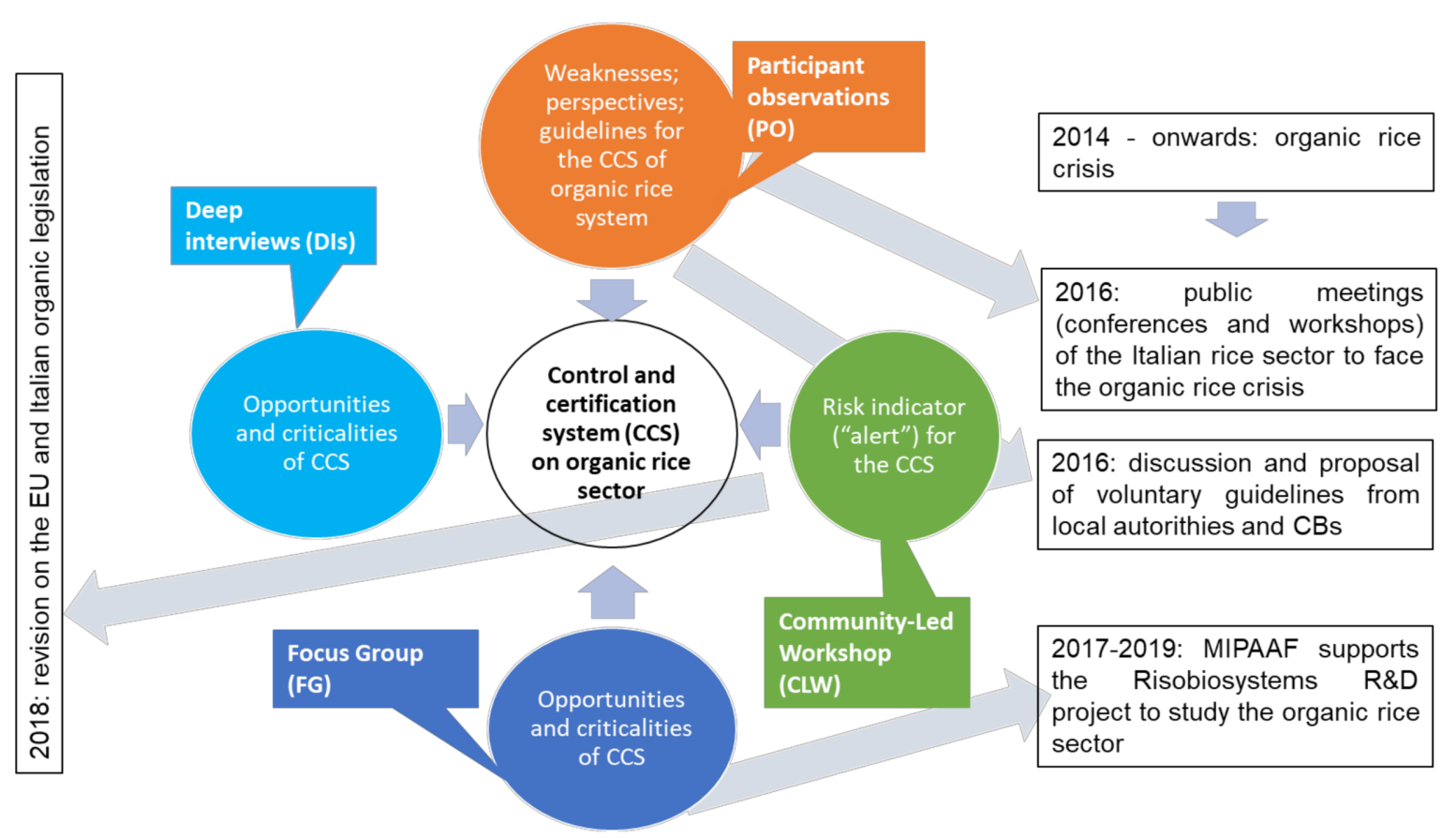

Figure 5. Themes associated with the type of research to improve the CCS and its relations with the organic rice context.

In particular, the investigation was carried out through (i) participant observations (POs) at SH meetings; (ii) community-led workshops (CLWs) according to the indications of Lawrence [38]; (iii) focus groups (FGs) to gain insights into the different aspects and dimensions of the issues [39], following the interpretation of Corrao [40], Zammuner [41], and Albanesi [42]; and (iv) deep interviews (DIs) with key informants, according to Guala [43] and Bichi [44] (Table 1).

The key informants (Table 2) were defined as the people who, by their role and experience, could provide a representative point of view of the SH group to which they belonged [45]. They were identified thanks to the indications received by SHs during previous research activities, as suggested by Reed [46].

Interviews, the FG, the CLW, and SH meetings were recorded and transcribed in Italian. Reduced transcriptions were corrected by the team, as suggested in Bertrand [47] and Krueger [48]. The analysis took place using an improved interactive reading grid during transcription analysis, as suggested by Dawson [49]. Statements relevant to the main questions of the research were identified and paraphrased. The occurring themes were identified, collected in a list, and summarized in English.

During data collection and analysis, various triangulation types were applied to ensure objectivity [50-52]. Data triangulation was applied by using different sources, i.e., sector legislation and various $\mathrm{SHs}$, whereas the method triangulation was achieved by using multiple qualitative methods to gather data. Investigator triangulation was ensured by the presence of several researchers collecting data, conducting the analysis, and discussing the results. 
Table 1. Details on fieldwork.

\begin{tabular}{|c|c|c|c|c|}
\hline Research Tool & When & Where & Participants & Topic \\
\hline POs & 24 May 2016 & $\begin{array}{c}\text { MiPAAF headquarters, } \\
\text { Rome }\end{array}$ & $\begin{array}{l}\text { Permanent organic } \\
\text { agriculture working group } \\
\text { established by MiPAAF }\end{array}$ & $\begin{array}{l}\text { Weaknesses of the organic rice } \\
\text { production and strategies to } \\
\text { improve the CCS and the } \\
\text { quality of organic rice for the } \\
\text { consumers and } \\
\text { the environment }\end{array}$ \\
\hline POs & 16 June 2016 & $\begin{array}{l}\text { CREA-Research } \\
\text { Centre for Cereals and } \\
\text { Industrial Crops, } \\
\text { Vercelli }\end{array}$ & $\begin{array}{l}\text { Organic and conventional } \\
\text { farmers, public authorities, } \\
\text { researchers, farmers' unions }\end{array}$ & $\begin{array}{l}\text { Conference on the } \\
\text { perspectives for the organic } \\
\text { rice sector }\end{array}$ \\
\hline POs & 12 October 2016 & $\begin{array}{l}\text { Lombardy region } \\
\text { headquarters, Milan }\end{array}$ & $\begin{array}{l}\text { Organic rice working group } \\
\text { (public authorities, } \\
\text { researchers, organizations } \\
\text { from the organic agriculture } \\
\text { supply chain) }\end{array}$ & $\begin{array}{l}\text { Discussion of the } \\
\text { development of guidelines for } \\
\text { the CCS of organic rice }\end{array}$ \\
\hline POs & 12 December 2016 & $\begin{array}{l}\text { Piedmont region } \\
\text { headquarters, Turin }\end{array}$ & $\begin{array}{l}\text { Organic rice working group } \\
\text { (public authorities, } \\
\text { researchers, organizations } \\
\text { from the organic agriculture } \\
\text { supply chain) }\end{array}$ & $\begin{array}{l}\text { Discussion of the } \\
\text { development of guidelines for } \\
\text { the CCS of organic rice }\end{array}$ \\
\hline CLW & 25 January 2018 & $\begin{array}{l}\text { Candia Lomellina } \\
\text { (Pavia), organic } \\
\text { rice farm }\end{array}$ & $\begin{array}{l}\text { Selected organic rice farmers, } \\
\text { researchers, and public } \\
\text { officials involved in the } \\
\text { multi-actor research network } \\
\text { of the Risobiosystems project }\end{array}$ & $\begin{array}{l}\text { Discussion of the matter of } \\
\text { the productivity of organic } \\
\text { rice and of the use of yields as } \\
\text { a risk indicator ("alert") for } \\
\text { the CCS }\end{array}$ \\
\hline FG & 15 February 2018 & $\begin{array}{l}\text { CREA-Italian } \\
\text { Research Centre for } \\
\text { Cereals and Industrial } \\
\text { Crops, Vercelli }\end{array}$ & $\begin{array}{l}\text { CBs responsible for the } \\
\text { certification of organic rice } \\
\text { production and } \\
\text { processing, researchers, } \\
\text { technicians, farmers }\end{array}$ & $\begin{array}{l}\text { The point of view of CBs on } \\
\text { CCS opportunities } \\
\text { and criticalities. } \\
\text { Existence of any bottlenecks }\end{array}$ \\
\hline DIs & March 2018 & SHs interviewed & 21 key informants(see Table 2) & $\begin{array}{l}\text { The point of view of SHs on } \\
\text { CCS opportunities } \\
\text { and criticalities. } \\
\text { Existence of any bottlenecks }\end{array}$ \\
\hline
\end{tabular}

Table 2. Stakeholders interviewed.

\begin{tabular}{cc}
\hline Key Informants & Identification Code \\
\hline Conventional rice farmer from the Piedmont region & KI1 \\
Conventional rice farmer from the Lombardy region and & KI2 \\
representative of the farmers' union & KI3 \\
Conventional rice farmer from the Lombardy region and expert & KI4 \\
Organic rice farmer from Lombardy, farm leader, and expert & KI5-KI6 \\
Organic rice farmer from the Lombardy region & KI5-KI7 \\
Organic rice farmer from the Piedmont region & KI8 \\
Public official of the Lombardy region & KI9 \\
Public official of the Piedmont region & KI10-KI11 \\
Public official of MiPAAF & KI12-KI13-KI14 \\
Representative of the farmers' union & KI15 \\
Representative of CCB & KI16-KI17-KI18-KI19-KI 20 \\
Researcher & KI21 \\
\hline
\end{tabular}




\section{Results}

The analysis of the legislative framework supported by the field analysis allowed us to highlight the SHs' perspectives on the CCS and some critical issues. Participant observations during four SH meetings made possible an understanding that the CCS of organic rice is a cause of great concern among all the actors in the rice sector. The first aspect that emerged clearly was the convergence of the SHs on the perception of a CCS weakened by the possibility of circumventing the rules of the current legislation and the risk that organic rice production loses credibility with consumers.

According to a widespread viewpoint among SHs, problems concerning the quality of organic rice are attributable primarily to the production phase and to a lesser extent to the following ones. It is at the level of rice farmers that, according to SHs, it is easier to circumvent the legislation on organic rice production.

Two agronomic factors are considered decisive to avoid frauds at the production level: the choice of rice varieties and the use of specific farming techniques that make it possible to avoid the use of synthetic pesticides to control pathogens and weeds. The SHs expressed the need for standardization and requested (i) a list of easily distinguishable varieties to be grown organically or conventionally, (ii) the definition of agronomic techniques that are practicable and therefore justified in organic rice cultivation, and (iii) an indication of the yields that are allowable in organic rice production.

The yield limit and the possibility of using average (limit) values as "alarm bells" for the control system were particularly discussed with contrasting points of view between the different SHs.

As one researcher clearly explained during an interview, yields of organic rice crops are on average lower than those obtained in conventional rice farming because they are not supported by chemical inputs. However, the lower yields are offset by higher prices on the market, which balances the disadvantages of this production system in terms of technical means. However, many organic producers report yields equal to or even higher than conventional ones. This is obviously a fraudulent situation that the CCS is currently unable to uncover.

During the CLW organized to deepen the theme of yields in organic rice cultivation, farmers and other SHs agreed that at the moment the average organic yields are lower than those obtained in conventional farming (from 20 to 30 percent less), but considered that productivity of organic rice has increased over the last few years as a result of the greater experience of farmers and their cooperation with researchers. In the most disadvantaged areas where conventional rice has never produced very high yields because chemical inputs are less effective, the distance with organic is reduced. In this case, rotations play a decisive role in crop performances, allowing for higher yields because rice pests are reduced. After three consecutive years of rice cultivation, however, production decreases considerably. High yields are the potential to be aiming for, which can be achieved with the continuous improvement of production techniques. Setting average values as an alert could limit this improvement work and discourage trustworthy farmers because of additional controls. Moreover, due to the diversity of environmental, soil, climatic, and agronomic situations in organic rice, it is not possible to set average values that fit well for every situation. It would be reasonable to establish ranges of production for each condition, but it would involve complex data collection and analysis. The group involved in the CLW concluded that using average yields as a risk indicator within the CCS is not particularly useful for preventing illegal behavior, because the fraudulent rice famer would be penalized in the income obtained (lower productions allowed to be declared per hectare), but not prevented from illegal activity. It was also suggested that in their control activity, the CBs should always consider the yield of the year and those of the previous years and should compare them with the rotation plan in order to verify whether they are compatible. 
Finally, the CLW made it possible to highlight that at the moment, the system of sanctions is too weak and needs to be toughened up. Indeed, in case of irregularities, the farmer is obligated to disqualify the production from organic and revert to conventional for two years, but only for the parcel where irregularities were found, without other penalties, while the certifier has no consequences at all. Farmers said that they are willing to undergo even stricter controls and penalties in order to get out of the situation of lack of transparency. They added that a major organic food distribution company is involving farmers in sales contracts that provide for further controls than those of the institutional system.

The FG with the CBs allowed the analysis on their responsibilities to be deepened. The CBs welcomed a reform of the certification system that can avoid possible conflicts of interest between them and the organic operators, for example by introducing tariff systems calculated on the service performed and not as a percentage of the turnover of the certified farm, prohibiting any form of participation in the ownership of the certified farm, etc. Furthermore, a shared code of ethics among CBs and common guidelines on issues not yet regulated by the legal provisions was hoped for, which would ensure greater uniformity in control and certification procedures.

Representatives of CBs also complained about the lack of a tougher sanctioning system, because downgrading the production from organic to conventional is judged insufficient to counter the widespread lack of legality among operators in the rice sector. A series of very concrete criticalities that the CBs face due to this attitude and that would require corrective interventions in the CCS was raised. This included interventions that should involve the entire sector in order to create a supportive, technical, and also cultural context. From a regulatory point of view, for example, eliminating the use of exemptions for "mixed" organic-conventional farmers and the possibility of cultivating the same variety of rice with both methods (conventional and organic) in mixed farms could facilitate the CBs' control tasks, eliminating potentially contradictory situations and therefore risk of illegality.

The analysis conducted by the representatives of the CBs during the FG made it possible to draw up a list of critical issues and corresponding intervention proposals (Table 3) that have to do with the entire production system and that require a praxeological change that should affect not only the CBs, but also the rice farmers and all the other actors, including researchers, advisors, institutions, etc.

From the in-depth interviews with key informants, it emerged quite clearly that the inefficiency of the CCS should not be attributed only to the system itself, but also to a lack of lawfulness that has affected the entire sector.

A conventional rice farmer from Lomellina, in Lombardy, summarized well the loss of integrity that has affected the rice industry: "Morality has always been a flag for this sector, as well as professionalism. There are many concrete examples. But the price difference between organic and conventional is too high. Earnings are too tempting. The opportunity has made the thief man. Organic should be a choice of life, but prices have become the only motivation for conversion" (KI1).

Another key informant stated, "Those in the countryside know who does the treatments, even if the treatments are done at night to avoid being seen. In the fields where pesticide treatments are done there is no longer a blade of grass. And treatments with products based on algae, that have no agronomic effect but are allowed in organic, are noted in field notebooks for the sole purpose of justifying the traces of the tractor wheels in the field" (KI12).

The criticisms of the fake organic rice are unanimous, as is the lack of confidence in the current certification system and the sense of frustration for the situation of immobility in the sector. The interviewees proposed many practical and easily applicable solutions that are very close to those proposed by the CBs. This is a signal that there is a convergence not only in the perception of the difficulties but also in the ideas for possible solutions. However, most of the interviewees seemed skeptical about the possibility of their implementation. 
Table 3. Critical points and proposals emerged during the FG with CBs for improvement of the control and certification system.

\begin{tabular}{|c|c|c|c|}
\hline Issue & $\begin{array}{l}\text { Consequence for the } \\
\text { Control System }\end{array}$ & Proposal for CBs & Proposal for the Sector \\
\hline $\begin{array}{l}\text { Land fragmentation } \\
\text { (presence of numerous } \\
\text { plots on the same farm) }\end{array}$ & $\begin{array}{l}\text { Numerous checks and } \\
\text { long duration of checks }\end{array}$ & $\begin{array}{l}\text { Strengthening of the staff in charge. } \\
\text { Performing random sampling of } \\
\text { controls and using satellite } \\
\text { control systems }\end{array}$ & $\begin{array}{l}\text { Reflecting on the possibility of } \\
\text { the certification of mixed } \\
\text { farms (organic-conventional) }\end{array}$ \\
\hline High yields & $\begin{array}{l}\text { Risk of fraudulent } \\
\text { situation (conventional } \\
\text { certified as organic) }\end{array}$ & $\begin{array}{l}\text { CB inspectors training and experience } \\
\text { Recourse to inspection personnel } \\
\text { with specific and significant } \\
\text { experience with rice } \\
\text { Careful documentary analysis: } \\
\text { production plan for the current year, } \\
\text { analysis of previous years' yields, } \\
\text { analysis of data in official databases }\end{array}$ & $\begin{array}{l}\text { Raising awareness and } \\
\text { training rice producers on } \\
\text { alternative agronomic } \\
\text { techniques to the use of } \\
\text { chemical treatments * }\end{array}$ \\
\hline $\begin{array}{l}\text { Submersion of rice fields } \\
\text { just before sowing and/or } \\
\text { absence of green manure } \\
\text { in pre-sowing }\end{array}$ & $\begin{array}{l}\text { Risk of fraudulent } \\
\text { situation (weeding against } \\
\text { crodo rice that is not edible) }\end{array}$ & $\begin{array}{l}\text { CB inspector training and experience } \\
\text { Recourse to inspection personnel } \\
\text { with specific and significant } \\
\text { experience with rice } \\
\text { Associating the evaluation of the field } \\
\text { conditions (visual observation) with } \\
\text { the floristic analysis and that of the } \\
\text { soil, water, and green plants }\end{array}$ & $\begin{array}{l}\text { Raising awareness and } \\
\text { training rice farmers on } \\
\text { alternative agronomic } \\
\text { techniques to the use of } \\
\text { chemical treatments * }\end{array}$ \\
\hline $\begin{array}{l}\text { Use of modern varieties, } \\
\text { e.g., not very resistant to } \\
\text { brusone (rice blast) }\end{array}$ & $\begin{array}{l}\text { Risk of fraudulent } \\
\text { situation (conventional } \\
\text { certified as organic) }\end{array}$ & $\begin{array}{l}\text { Surveyor training and experience } \\
\text { Recourse to inspection personnel } \\
\text { with specific and significant } \\
\text { experience with rice }\end{array}$ & $\begin{array}{l}\text { Investment in various } \\
\text { research programs (genetic } \\
\text { improvement and variety } \\
\text { of selection) }\end{array}$ \\
\hline $\begin{array}{l}\text { Massive use of fertilizing } \\
\text { or corroborating products } \\
\text { allowed in organic } \\
\text { farming, without adequate } \\
\text { agronomic or } \\
\text { economic justification }\end{array}$ & $\begin{array}{l}\text { Risk of a fraudulent } \\
\text { situation (use of } \\
\text { unallowed fertilizers in a } \\
\text { mixture, difficult } \\
\text { to identify) }\end{array}$ & $\begin{array}{l}\text { CB inspector training and experience } \\
\text { Recourse to inspection personnel } \\
\text { with specific and significant } \\
\text { experience with rice production } \\
\text { Agronomic surveys that allow for } \\
\text { feedback on the correspondence } \\
\text { between the technique used and the } \\
\text { evidence in the field }\end{array}$ & $\begin{array}{l}\text { Raising awareness and } \\
\text { training rice farmers on } \\
\text { alternative agronomic } \\
\text { techniques to the use of } \\
\text { chemical treatments * }\end{array}$ \\
\hline $\begin{array}{l}\text { Presence of residues from } \\
\text { chemical treatments }\end{array}$ & $\begin{array}{l}\text { Risk of a fraudulent } \\
\text { situation or accidental } \\
\text { contamination due to the } \\
\text { drift of pesticides and } \\
\text { entry of polluted waters } \\
\text { from conventional } \\
\text { rice farmers }\end{array}$ & $\begin{array}{c}\text { CB inspector training and experience } \\
\text { Recourse to surveyor personnel with } \\
\text { specific and significant experience } \\
\text { with rice } \\
\text { Agronomic surveys associate the } \\
\text { evaluation of the field conditions } \\
\text { (visual observation) with the floristic } \\
\text { analysis and that of the soil, water, } \\
\text { and green plants ** }\end{array}$ & $\begin{array}{l}\text { Adoption of protection } \\
\text { measures against accidental } \\
\text { contamination: environmental } \\
\text { areas such as ditches, } \\
\text { channels, rows, hedges } \\
\text { Prohibition of submersion of } \\
\text { paddy chambers during } \\
\text { chemical treatments in } \\
\text { neighboring paddy fields }\end{array}$ \\
\hline
\end{tabular}

* Green mulch with cover crops, transplanting rice seedlings that, being in the tillering stage, are able to prevail over the development of weeds, etc. ${ }^{* *}$ CBs report that the intermediate laboratory analyses (in the pre-sowing and sowing phase), even if they cannot determine the final outcome of the control based on the results of the controls on the final product, support analyzing risks and identifying the critical control period.

The state of crisis that prevents any action is caused by strong economic interests, conflicts, and distrust that pervade the sector. The prices of organic rice have pushed up land lease and purchase costs for all rice farmers, both organic and conventional, and have increased speculation. Speaking of the need for transparency and traceability of the supply chain, an interviewee explains, "Traceability verification is possible because the information base exists. There are various public databases available, there is the information held by the insurance companies, that can be obtained from the applications for public contributions but it is necessary a crossover of data that allows to carry out a 
check, for example on production yields and mixed farms. Obviously false data would turn up. Who is hampering more transparency? There is a complicity of the whole system in maintaining the opacity of the rice chain. The sector is very conflicting (young people against the big ones, provinces against each other, rice mills and rice farmers do not collaborate), there are strong market interests (organic prices are double or even triple compared to the conventional), conflicts of interest are present in the representative bodies. All this ensures that nobody trusts anyone" (IC12).

"Seriousness and ethics" are the key words mentioned by the interviewees. An organic rice farmer summarized, "Organic is a possible, but difficult, reality. It is an ethical discourse: the desire and the duty to aim for the best. I have not maximized the profit with organic agriculture but my personal expectations" (KI4).

It emerged clearly that the certification system can be improved, but the sector needs a cultural and ethical revolution that invests all the actors not only in the sector, but in all organic: "Organic rice could be a fuse for a large revolution" (KI4).

In this sense, the demonstration that organic rice can be cultivated in a responsible and remunerative manner, the dissemination of good practices among rice farmers, and the collaboration with the research institutions and extension services make it possible to extend the organic method to trustworthy rice farmers by gradually isolating the untrustworthy ones. "Around the organic rice, large economic interests revolve, the certified organic rice has reached 700-800 euros per ton. It is normal that there are tensions and conflicts, but it is necessary to set a good example. The goal is to demonstrate that the true organic rice can be made, without waging war, but through the way of example, of dissemination: moments of dissemination extended to people interested in organic organized by trustful farmers" (KI8).

The analysis of key SH interviews showed that the heterogeneity of criticalities in the CCS can find an answer in compulsory adjustments of the regulatory system. However, it is also considered important to implement voluntary self-control measures at the farming level, agreed between the farmers and the other actors in the chain and aimed at restoring a condition of widespread trust.

Moreover, several measures emerged from the interviews with key informants to foster the improvement of the whole supply chain: measures to encourage group certification as a tool for mutual control and training among farmers, making use of commercial contracts that provide for compliance with more stringent regulations than those of organic certification as a guarantee for producers and consumers, introducing incentives for farmers that operate exclusively in the organic sector ("dedicated organic supply chain"), and ensuring greater integrity of the entire supply chain through a series of collaboration initiatives between different actors. At the production level, greater discussion between farmers, sharing of experiences and good practices, mutual knowledge, socialization, and collaboration could trigger processes of emulation, healthy competition, and isolation of unprofessional farmers. At the level of the supply chain, the establishment of working groups that favor moments of discussion between institutions, researchers, agricultural associations, and other supply chain actors could encourage the design and coordination of actions aimed at ensuring the integrity of the sector, filling a void left by the public authority.

\section{Discussion and Conclusions}

Organic agriculture and its certification system pose a great challenge for producers as well as controllers to ensure the authenticity and high quality of the products. What Smithers and Joseph [15] said about the authenticity of farmers' markets is also very true for organic: "At this time, and perhaps for the foreseeable future, authenticity remains a strong organizing principle that finds its expression in ways and by degrees that defy easy calibration. The open question of what constitutes a real FM is both a challenge and an opportunity for scholars wishing to better theorize the nature of authenticity (or quality, legitimacy, etc.) and to capture the geographical diversity and empirical richness of this important concept as it continues to evolve in practice and scholarship". 
Michelsen [20] explained that organic farming aims at developing self-regulating sustainable farming systems and seems to be an important example of environmental self-regulation with a strong basis in values. Political acknowledgement of organic farming included the introduction of public certification, but this may disturb self-regulation. Examining the Danish case, the author concluded that originally public certification of organic products was introduced on the basis of close cooperation with the organic farming movement, but the introduction of the European Union certification gradually undermined cooperation and the organic social movement has now lost control over production standards. Danish organic farmers seem, on the other hand, prepared to develop and use new methods of self-regulation. The farmers agree well with the fundamental values of organic farming, they do not violate the standards, and they are interested in active use of organic farming values in farm management.

The process described by Michelsen [20] is based on values and precisely the common values intimately felt by farmers find the impetus to evolve over time. Our case study seems to have a similar trajectory. The process of recognizing a diversity of values underlying the choice of organic and the ability of the current CCS to support those that should be founding organic is still at an early stage and, from the results of the survey, it is not possible to understand whether it will actually evolve in this direction. The widespread negative perception of SHs on the efficiency of the actual CCS and the desire of some rice farmers to resort to even stricter but credible alternative systems (what Poméon et al. [53] called private "bio +" standards that go beyond the regulated organic requirements) suggest that "while the conventional third party certification remains the dominant institutional frame, there is space for competing schemes" [54].

In our case study a distribution company invited some farmers to adhere to a stricter regulation of organic production, ensuring in return a secure sales channel. This proposal has found good interest on the part of organic rice growers, demonstrating the key role of intermediaries in the way farmers may participate in alternative organic standards in agri-food value chains, as already showed by Lemeilleur [55].

As Niederle et al. [54] pointed out, the relevance of the alternatives depends on the skills possessed by the agent who is pushing the change (i.e., a social movement or a network). In our case, it appears to be still in an embryonic state because it involves only a small group of rice farmers. Needing a broader membership, it has not yet involved the final consumers and does not have a clear and recognizable shape towards the outside.

Darnhofer et al. [21] argued that the organic sector emerged based on relations between organic actors, policymakers, mainstream farmers associations, advocacy groups, and actors along the food chain. These relations depend on the temporal and the spatial context. By framing the organic system as an ensemble of social relations rather than a field of invariant logic and automatic unfoldings, the relational perspective emphasizes the importance of seizing windows of opportunity, and the role of creativity in actions. This evidence can also be extended to the certification system for which the particular historical moment and the social context can affect its effectiveness, as we saw in our case study. In this sense, the certification system should be able to adapt to the changing context. However, a system based on rules and procedures defined by law, even at the level of the European Union, as is the case in Italy, can be expected to change slowly. For example, in Italy, with the current capacity of CBs, it was stated that it would take several decades to perform thorough inspections assuring that standards are fully met [56]. Therefore, it seems necessary that it can be integrated by actions that come "from below," of a spontaneous and cooperative type aimed at recreating that system of self-regulation referred to by Michelsen [20].

Studying the halal food supply chain, which has issues of quality and authenticity similar to those of the organic supply chain, Ali et al. [57] found that a strategy of customer and supplier integration had a positive impact on the supply chain integrity.

According to Freyer et al. [23], today, organic actors embody a mix of traditional and new values that manifest themselves in the diversity of types and practices of organic 
farms, the variety of markets for organic products, and the range of consumers' values about organic. The values of organic pioneers continue, but they are expressed in diverse patterns within the organic movement.

The discussion among the various actors that is taking place within the Italian rice sector, not only organic, demonstrates precisely this need to reconcile old and new values $[24,58]$. Moreover, a certification system that is able to incorporate the results of this discussion appears to be at least desirable. In our work, we have shown that a reflection on the legislation alone is not enough to intercept the factors that cause the ineffectiveness of the control and certification system.

Instead, the participatory analysis of critical issues and opportunities, extended to all the actors involved, through what Alrøe and Noe [59] called a "polyocular approach" that facilitates a comprehensive and balanced understanding of the dynamics and governance of organic agriculture, provides useful indications that go well beyond the scope of the CCS and includes an ethical and cultural change in the sector, and an educational intervention that supports such change.

Arcuri [26] explained that the regulatory regime for organic products evolved from purely private regulatory schemes into minimum public standards in a process of "publicisation" that has empowerment and containment effects at the same time, affecting both the regulatory capabilities of private regulators as well as the quality of the standards.

In this article the desirability of governmental intervention in the CCS is not questioned, but it is suggested that the government should be able to dialogue with private actors. The Italian case of organic rice was investigated to better understand which critical issues must be taken into consideration to make governmental and private interventions coexist, dynamically interact, and integrate.

To answer the research questions, all the considerations made above lead to saying that the responsibility of the efficiency of the CCS is to be shared between all the players in the supply chain and not attributed only to the CCS itself.

To facilitate this process, a revision of the policy and legislation framework should set up a well-functioning quality-assurance system at the national level and should provide financial incentives and technological services for improving managerial and technical skills at different levels of the CCS [60].

The evolution of the EU legislation on both organic farming and the official control (Reg. 2017/625) as well as their adaptation in the Italian legislation seem to lead to this direction. Indeed, the new organic regulation (Regulation (EU) 2018/848) introduces both group certification (including cross-border certification) that will enable small producers to join the organic system, and the provision for the elimination of derogations for mixed organic-conventional farms.

After 1 January 2017, supervision and control activities were strengthened by the operation of CUTFAA, which, in exercising its control function on the safety of the food supply chain, carries out surveillance activities on the CBs.

Decree 6793 from 18 July 2018 also strengthened the traceability system of the organic rice supply chain through the collection and processing of sector information transmitted to the Ente Nazionale Risi. In particular, Art. 8 obliges producers to declare areas and productions; storage centers must declare stocks, distinguishing between conventional, organic, and in conversion; and CBs must periodically transmit information on the control activity carried out at operators' premises and data on operators (number of operators entering and leaving the control system, areas and yields for each production orientation, and information on the type of processing activity and production value).

With regard to the diversified control protocols, a strict package of agronomic solutions and production techniques should be defined and diversified according to the type of soil, variety, and availability of water in order to allow the various organic farms to join the solution that is best suited to their conditions. This would allow pre-established specific solutions to be defined, allowing for the avoidance of the use of techniques that, due to economic opportunities, risk compromising the quality of the product and permit more 
standardized and specific controls. Adherence to the protocol should provide for high penalties in the event of failure to comply with the production requirements.

The use of floristic and/or agronomic analysis is considered important so the evidence and the results of laboratory analysis assume, within the certification procedure, a strategic value, especially in the case of different methods of production even for the same variety (organic and conventional). The admissibility of mixed farms should only be provided in the case of the adoption of sustainable farming methods (integrated production as a certifiable method) on the entire farm surface, with the commitment to fully converting the farm within a medium-long term (almost five years).

Zezza et al. [61], with regard to the Italian organic food sector, found that the probability of being sanctioned is higher from CBs that make a higher number of unannounced visits or sample tests. Similar conclusions have also been found in Germany for food quality controls [29,33,62]. Analogous results where shown by [63] that estimated the chance of detected non-compliances with regard to the adopted procedures of a CB in Italy.

Standardization of procedures is an important step in enhancing control reliability in the organic sector. Rotation of CBs and inspectors on one side and further standardization of fees and procedures could be other steps in this direction that would enhance the creation-level playing field between control bodies and reduce competition for customers on the basis of a less rigorous system. Third-party audits represent a relevant cost for producers, processors, and other operators of the organic value chain. If well run, all operators could contribute to increasing the food quality system [61].

Another aspect that should be improved is the training of technicians and operators. Training should be provided along the organic rice food supply chain in order to increase transparency and the linkages between actors, as well as to improve specific managerial skills for better production planning. The specialized training of consultants who carry out inspections on behalf of CBs should also be developed, since rice cultivation is very technical and requires a good level of experience.

Interestingly, since 2017, the United States Department of Agriculture (USDA) has offered an award to CBs that regularly go beyond the basic requirements and provide more comprehensive data on certified operations through the Organic INTEGRITY Database. Better data deters fraud, helping to ensure consumers' confidence in the CCS. Data quality minimum standards and best practices have been incorporated into Certifier Data Quality Profiles that help CBs assessing their activity and performance and show where they could improve.

Such an example could be useful to implement in Italy.

An analysis of the organic rice system after the implementation of new Regulation (EU) 2018/848 would allow our findings to be compared to the new legal framework, as it would also be relevant to introduce a new product specification of the organic rice value chain. In that case, considering the consumers' point of view could also be a worthy aspect to assess.

Author Contributions: This paper is the result of teamwork. G.D.G. conceived the research question and the research design; discussed the results, review and, editing of the paper; and carried out the supervision. E.P. contributed to the funding acquisition; conceived the research question and the research design; conducted the investigation and analyzed the data; wrote the Introduction, Materials and Methods, and Results sections; and reviewed the final paper. I.B. conceived the research design, conducted the investigation and analyzed the data, and wrote the Discussion section. A.V. wrote the Introduction section and discussed the results. P.B. conceived the research design; conducted the investigation and analyzed the data; discussed the results and wrote the Introduction, Results, and Discussion sections; and carried out the supervision. All authors have read and agreed to the published version of the manuscript.

Funding: This study was carried out as part of the Risobiosystems R\&D Project (2017-2020) funded by the Italian Ministry of Agriculture, Food and Forestry Policies (MiPAAF-D.M. N.94667 19/12/2016) in support of the organic rice sector. MiPAAF did not have any role in the design of the study, in the collection, analysis, and interpretation of the data, or in the writing of the manuscript. 
Institutional Review Board Statement: This study was conducted in compliance with the CNR Code of Conduct of 20 October 2017, whose observance is supervised by the Institute Director. Not applicable for the analysis conducted by CREA.

Informed Consent Statement: Not applicable.

Data Availability Statement: The data supporting the findings of this study (audio recordings of the interviews; direct observation notes) are not publicly available, as they contain information that may compromise the privacy of those participating in the research, but are available from the corresponding author on reasonable request.

Acknowledgments: The authors wish to greatly acknowledge all the stakeholders involved in the interviews and focus groups for their kind availability in sharing their time, knowledge, and experiences. The interpretations in this article remain the authors' own. The authors would like to thank the reviewers for their useful critical comments and suggestions for the early drafts of this manuscript. The authors would like to thank Eligio Malusà (CREA Research Centre for Viticulture and Enology) for his re-reading of the paper and for improving the English.

Conflicts of Interest: The authors declare no conflict of interest.

\section{References}

1. FAO Organic Agriculture. Available online: http://www.fao.org/organicag/oa-faq/oa-faq2/en/ (accessed on 5 January 2021).

2. European Commission Becoming an Organic Farmer. Available online: https://ec.europa.eu/info/food-farming-fisheries/farmi ng/organic-farming/becoming-organic-farmer_en (accessed on 5 January 2021).

3. MiPAAF Elenco Organismi di Controllo Autorizzati per le Produzioni Biologiche. Available online: https://www.politicheagric ole.it/flex/cm/pages/ServeAttachment.php/L/IT/D/d\%252Ff\%252F1\%252FD.95c0bcf72943e07b39bb/P/BLOB\%3AID\%3D6 189/E/pdf (accessed on 22 October 2020).

4. $\quad$ Kristiansen, P.; Taji, A.; Reganold, J. Organic Agriculture: A Global Perspective; CSIRO; Wallingford/Cornell University Press: Collingwood, Australia, 2006.

5. Evenson, R.E.; Gollin, D. Genetic Resources, International Organizations, and Improvement in Rice Varieties. Econ. Dev. Cult. Chang. 1997, 45, 471-500. [CrossRef]

6. GRiSP (Global Rice Science Partnership). Rice Almanac, 4th ed.; International Rice Research Institute: Los Baños, Philippines, 2013.

7. FiBL Statistics. Research Institute of Organic Agriculture (FiBL): Frick, Switzerland. Available online: https://statistics.fibl.org/ (accessed on 22 October 2020).

8. Willer, H.; Schaack, D.; Lernoud, J. Organic Farming and Market Development in Europe and the European Unione. In The World of Organic Agriculture-Statistics and Emerging Trends; IFOAM: Bonn, Germany, 2017; pp. 207-243.

9. IFOAM. The World of Organic Agriculture 2016: Statistics and Emerging Trends; IFOAM: Bonn, Germany, 2016.

10. European Commission. EU agricultural outlook for the agricultural markets and income 2017-2030. DG Agriculture and Rural Development; Publications Office of the European Union: Brussels, Louxemburg, 2019.

11. EUROSTAT Data Browser. Available online: https://ec.europa.eu/eurostat/databrowser/product/page/ORG_CROPAR (accessed on 22 October 2020).

12. SINAB Superfici Biologiche per Anno, Prodotto e Regione. Available online: http://www.sinab.it/content/superfici-biologiche -anno-prodotto-e-regione (accessed on 21 November 2020).

13. Orlando, F.; Alali, S.; Vaglia, V.; Pagliarino, E.; Bacenetti, J.; Bocchi, S. Participatory approach for developing knowledge on organic rice farming: Management strategies and productive performance. Agric. Syst. 2020, 178, 102739. [CrossRef]

14. Pagliarino, E.; Orlando, F.; Vaglia, V.; Rolfo, S.; Bocchi, S. Participatory research for sustainable agriculture: The case of the Italian agroecological rice network. Eur. J. Futur. Res. 2020, 8, 1-16.

15. Smithers, J.; Joseph, A.E. The trouble with authenticity: Separating ideology from practice at the farmers' market. Agric. Hum. Values 2010, 27, 239-247. [CrossRef]

16. Parrott, N.; Olesen, J.E.; Hogh-Jensen, H. Certified and non-certified organic farming in the developing world. In Global Development of Organic Agriculture: Challenges and Prospects; CAB International: Wallingford, UK, 2006; pp. $153-176$.

17. Loconto, A.M. Labelling the Economy; Laurent, B., Mallard, A., Eds.; Springer: Singapore, 2020.

18. Darnhofer, I.; Lindenthal, T.; Bartel-Kratochvil, R.; Zollitsch, W. Conventionalisation of organic farming practices: From structural criteria towards an assessment based on organic principles. A review. Agron. Sustain. Dev. 2010, 30, 67-81. [CrossRef]

19. Nelson, E.; Tovar, L.G.; Rindermann, R.S.; Cruz, M.Á.G. Participatory organic certification in Mexico: An alternative approach to maintaining the integrity of the organic label. Agric. Hum. Values 2010, 27, 227-237. [CrossRef]

20. Michelsen, J. Organic farming in a regulatory perspective. The Danish case. Sociol. Rural. 2001, 41, 62-84. [CrossRef]

21. Darnhofer, I.; D'Amico, S.; Fouilleux, E. A relational perspective on the dynamics of the organic sector in Austria, Italy, and France. J. Rural. Stud. 2019, 68, 200-212. [CrossRef]

22. Dufeu, I.; Le Velly, R.; Bréchet, J.P.; Loconto, A. Can standards save organic farming from conventionalisation? Dynamics of collective projects and rules in a French organic producers' organisation. Sociol. Rural. 2020, 60, 621-638. [CrossRef] 
23. Freyer, B.; Bingen, J.; Klimek, M. Framework for Re-thinking Ethics in the Organic Movement. In Re-Thinking Organic Food and Farming in a Changing World. The International Library of Environmental, Agricultural and Food Ethics; Springer: Dordrecht, The Netherlands, 2015; pp. 259-308.

24. Padel, S. Values of organic producers converting at different times: Results of a focus group study in five European countries. Int. J. Agric. Resour. Gov. Ecol. 2008, 7, 63. [CrossRef]

25. Prudham, S.; MacDonald, K.I. Qualifying tradition: Instituted practices in the making of the organic wine market in LanguedocRoussillon, France. J. Agrar. Chang. 2020, 20, 659-681. [CrossRef]

26. Arcuri, A. The Transformation of organic regulation: The ambiguous effects of publicization. Regul. Gov. 2015, 9, 144-159. [CrossRef]

27. Pyburn, R.; Sriskandarajah, N.; Wals, A.E.J. Social Responsibility in Organic Agriculture: Learning, Collaboration and Regulation. In Organic Agriculture A Global Perspective; Kristiansen, P., Taji, A., Renagold, J., Eds.; Cornell University Press: Ithaca, NY, USA, 2006; pp. 329-350.

28. Sacchi, G.; Caputo, V.; Nayga, R. Alternative Labeling Programs and Purchasing Behavior toward Organic Foods: The Case of the Participatory Guarantee Systems in Brazil. Sustainability 2015, 7, 7397-7416. [CrossRef]

29. Albersmeier, F.; Schulze, H.; Jahn, G.; Spiller, A. The reliability of third-party certification in the food chain: From checklists to risk-oriented auditing. Food Control. 2009, 20, 927-935. [CrossRef]

30. Canavari, M.; Spadoni, R.; Pignatti, E. Ruolo della certificazione Dei prodotti da agricoltura biologica nei confronti di produttori, filiera, consumatori e autorità pubbliche. In Prospettive Dell'Agricoltura Biologica in Italia; De Stefano, F., Cicia, G., Eds.; Edizioni Scientifiche Italiane: Napoli, Italy, 2008.

31. De Gennaro, B.; Roselli, L. Un'Analisi Della Struttura E Del Funzionamento Del Sistema DI Controllo E Certificazione Delle Produzioni Da Agricoltura Biologica. In Agriregioneuropa, year $4 n^{\circ} 15$; Associazione Alessandro Bartola Editor: Ancona, Italy, 2008.

32. Zucaro, R. Il Sistema di Controllo dei Prodotti Biologici in Italia; INEA: Rome, Italy, 2013.

33. Zorn, A.; Lippert, C.; Dabbert, S. Supervising a system of approved private control bodies for certification: The case of organic farming in Germany. Food Control. 2012, 25, 525-532. [CrossRef]

34. Zorn, A.; Lippert, C.; Dabbert, S. An analysis of the risks of non-compliance with the European organic standard: A categorical analysis of farm data from a German control body. Food Control. 2013, 30, 692-699. [CrossRef]

35. Gambelli, D.; Solfanelli, F.; Zanoli, R. Improving controls in organic farming by timely inspections: A statistical analysis. Biol. Agric. Hortic. 2018, 34, 186-198. [CrossRef]

36. Padel, S. The European Regulatory Framework and its Implementation in Influencing Organic Inspection and Certification Systems in the EU. 2010. Available online: https: / / orgprints.org/17338/ (accessed on 5 January 2021).

37. Fagotto, E. Private roles in food safety provision: The law and economics of private food safety. Eur. J. Law Econ. 2014, 37, 83-109. [CrossRef]

38. Lawrence, D.; Christodoulou, N.; Whish, J. Designing better on-farm research in Australia using a participatory workshop process. Field Crop. Res. 2007, 104, 157-164. [CrossRef]

39. Bryman, A. Social Research Methods / Alan Bryman, 3rd ed.; OU Press: New York, NY, USA, 2008.

40. Corrao, S. Il Focus Group, 3rd ed.; Franco Angeli Ed: Milano, Italy, 2005.

41. Zammuner, V. I Focus Group; Società editrice il Mulino: Bologna, Italy, 2003.

42. Albanesi I Focus Group; Carocci: Roma, Italy, 2005.

43. Guala, C. Interviste e Questionari Nella Ricerca Sociale Applicata; Rubbettino Editore: Soveria Mannelli (CZ), Italy, 2003.

44. Bichi, R. La Conduzione Delle Interviste Nella Ricerca Sociale; Carocci: Roma, Italy, 2007.

45. Brugha, R.; Varvasovszky, Z. Review article Stakeholder analysis: A review. Health Policy Plan. 2000, 15, 239-246. [CrossRef]

46. Reed, M.S.; Graves, A.; Dandy, N.; Posthumus, H.; Hubacek, K.; Morris, J.; Prell, C.; Quinn, C.H.; Stringer, L.C. Who's in and why? A typology of stakeholder analysis methods for natural resource management. J. Environ. Manag. 2009, 90, 1933-1949. [CrossRef] [PubMed]

47. Bertrand, J.T.; Brown, J.E.; Ward, V.M. Techniques for Analyzing Focus Group Data. Eval. Rev. 1992, 16, 198-209. [CrossRef]

48. Richard, A. Krueger Quality Control in Focus Group Research. In Successful Focus Groups: Advancing the State of the Art; Morgan, D.L., Ed.; SAGE: London, UK, 1993; pp. 65-85.

49. Dawson, S.; Manderson, L.; e Tallo, V.L. A Manual for the Use of Focus Group; Internatio: Boston, MA, USA, 1993.

50. Guion, L.A. Triangulation: Establishing the Validity of Qualitative Studies. Inst. Food Agric. Sci. Ext. 2002, 1-3.

51. Golafshani, N. Understanding reliability and validity in qualitative research. Qual. Rep. 2003, 8, 597-606.

52. Koro-Ljungberg, M. Validity and validation in the making in the context of qualitative research. Qual. Health Res. 2008, 18, 983-989. [CrossRef]

53. Poméon, T.; Loconto, A.; Fouilleux, E.; Lemeilleur, S. Organic farming in France: An alternative project or conventionalisation? In Ecology, Capitalism and the New Agricultural Economy—The Second Great Transformation, 1st ed.; Routledge: London, UK, 2018; Volume 1, 20.

54. Niederle, P.; Loconto, A.; Lemeilleur, S.; Dorville, C. Social movements and institutional change in organic food markets: Evidence from participatory guarantee systems in Brazil and France. J. Rural Stud. 2020, 78, 282-291. [CrossRef]

55. Lemeilleur, S. Smallholder compliance with private standard certification: The case of globalGAP adoption by mango producers in Peru. Int. Food Agribus. Manag. Rev. 2013, 16, 159-180. 
56. Favilli, E.; Rossi, A.; Brunori, G. Food networks: Collective action and local development. The role of organic farming as boundary object. Org. Agric. 2015, 5, 235-243. [CrossRef]

57. Ali, M.H.; Zhan, Y.; Alam, S.S.; Tse, Y.K.; Tan, K.H. Food supply chain integrity: The need to go beyond certification. Ind. Manag. Data Syst. 2017, 117, 1589-1611. [CrossRef]

58. Best, H. Organic agriculture and the conventionalization hypothesis: A case study from West Germany. Agric. Hum. Values 2007, 25, 95-106. [CrossRef]

59. Alrøe, H.F.; Noe, E. What makes organic agriculture move: Protest, meaning or market? A polyocular approach to the dynamics and governance of organic agriculture. Int. J. Agric. Resour. Gov. Ecol. 2008, 7, 5-22. [CrossRef]

60. Santacoloma, P. Organic Certification Schemes: Managerial Skills and Associated Cost. Synthesis Report from Case Studies in the Rice and Vegetable Sectors; FAO: Rome, Italy, 2007.

61. Zezza, A.; Demaria, F.; Laureti, T.; Secondi, L. Supervising third-party control bodies for certification: The case of organic farming in Italy. Agric. Food Econ. 2020, 8, 1-14. [CrossRef]

62. Padilla Bravo, C.; Villanueva Ramírez, I.; Neuendorff, J.; Spiller, A. Assessing the impact of unannounced audits on the effectiveness and reliability of organic certification. Org. Agric. 2013, 3, 95-109. [CrossRef]

63. Gambelli, D.; Solfanelli, F.; Zanoli, R. Feasibility of risk-based inspections in organic farming: Results from a probabilistic model. Agric. Econ. 2013, 45, 267-277. [CrossRef] 